\title{
POSSIBLE RAPID METHOD FOR THE DETERMINATION OF CONCRETE'S FROST RESISTANCE
}

\author{
Dr Sergey Nikolskiy* \\ Saint Petersburg State Polytechnical University, Saint Petersburg, Russia \\ Dr Nikolay Vatin \\ Saint Petersburg State Polytechnical University, Saint Petersburg, Russia \\ Olga Pertseva \\ Saint Petersburg State Polytechnical University, Saint Petersburg, Russia
}

During this research, the theoretical analysis of dependence concrete's frost resistance of sample and energy, which is emitted by a sample at destruction, was carried out. The offered method includes measurement of residual deformation of a sample after the one cycle of freezing defrosting, measurement of long strength and measurement of short-term strength. Frost resistance of a sample is as the mathematical relation of these energies, and the frost resistance of concrete is calculated as arithmetic mean on samples. The offered method doesn't demand long tests, it's high efficiency and wide scope, but special laboratory equipment is necessary.

Key words: Frost resistance, concrete, Dilatometric method, Non-destructive loading, Acoustic issue

\section{INTRODUCTION}

For determining the concrete mix composition it is necessary to take into account frost resistance. Frost resistance of concrete is ability of water-saturated concrete sample to maintain repeated standard thermo cycles without noticeable damage.

If filling concrete's pores water turn into ice, it will increase in volume and cause concrete's micro cracks. When number of cycle freezing-defrosting increases, damages of concrete are collected, and its durability decreases [24, 25]. Also different types of water pressure cause concrete's frost deterioration, such as hydraulic and osmotic pressure [37], capillary pressure [12] and other types of water influence according to existing theory of frost resistance [18]. Decreasing strenght of construction material is associated with the processes of its water freezing (for example, rock [24, 22]). Water gets into structure of porous bodies, separates particles and breaks coupling between them [11]. Porosity of material is determinative factor for frost resistance and durability subsequently [38, 39]. So, strength of concrete could be pictured as a porosity function [23].

Of course, at the present time analytical [45] or computational methods allow to simulate concrete behavior under service conditions and estimate durability of material [10], but every research need to be proven by testing nature sam- ples [43] and good data base [44]. In worldwide experience there are some test methods to determine durability of concrete by frost damage, such as Slab test For determining the concrete mix composition it is necessary to take into account frost resistance [40], CDF [36], CIF-Test [35] and Cube-Test [10]. These test methods contain follow steps: curing and preparing the samples, pre-saturation samples and thermo cycling of them. The test liquid simulates a deicing agent and contains $3 \%$ by weight of $\mathrm{NaCl}$ and $97 \%$ by weight of (demineralized) water in case of the test of the freeze-thaw and deicing salt resistance and demineralized water to test the freeze-thaw resistance of concrete respectively. Scaling of the samples is measured after a well defined number of freeze-thaw cycles and leads to an estimate of the resistance of the tested concrete against frost damage. The test methods differ however in their procedures and conditions. So at CIF test contain determination of internal damage by measuring of the relative dynamic modulus of elasticity (to take into account ultrasonic transit time) [16]. Also there are some models of labor concrete damage due to cyclic freezing and thawing, for example interaction of load and freeze-thaw cycles with chloride exposure regime on surface scaling process of concrete and the internal cracking process [23]. There are two different standard types of methods of determination concrete's frost resistance 
- basic and rapid in Russian Federation.

Basic methods [19] include production and test of samples by series. Further, all samples have been sated by water and part of samples have been alternated repeating freezing and defrosting. After that all samples have been destroyed by compression. For comparison of average values of strength, both types of samples are taken: tested with freezing defrosting, and not. The next step is to define relative decreasing in strength of material under different number of term cycles. Concrete's frost resistance is defined by number of thermo cycles, which necessary for decreasing in strength in limits, stipulated by the standard [51-55].

During estimation of concrete's frost resistance considerable random dispersion of values of concrete strength (variation coefficient $\rho=15 \ldots$ $20 \%$ ) [16] under invariable conditions of production and tests of samples gives rise to a wide scatter of average values of strength and demands large volume test (quantity of test pieces $25 \ldots 50$ ) as proof that relative decreasing in strength of $\Delta R / R=0,05 \ldots 0,15$ as a result of freezing defrosting.

Therefore, the basic methods have two main weaknesses: high labour input and small operability. Determination of frost resistance by basic methods takes big time intervals (from 1 to 6 months), so the rapid methods are necessary.

One of the existing rapid methods is a "Dilatometric rapid method for the determination of frost resistance" [19]. This method is a prototype for method, which has been offered by me. Dilatometric rapid method for the determination of frost resistance includes production of concrete samples, measurement of samples, determination of initial volume, saturation of samples by water, simultaneous freezing of each sample sated with water and a standard sample in the dilatometer up to the standard temperature and measurement thus differences of values of volume deformations of the concrete and standard samples (relative changing of volume). Concrete's frost resistance is established by the maximum relative difference of volume deformations of the concrete and standard samples in accordance with tables provided in standard specification [19] taking into account a type of concrete, a form and the size of samples [03-08].

However, the results from tables provided in state standard specification are acceptable only for concrete on a Portland cement and slag Portland cement without surface-active additives (PEAHENS), such concretes are used extremely seldom now. Now lot of new concretes are investigated [47], tested and used, for example, nanomodificated concete [21, 44], high-strength concrete $[22,33]$, concrete on the basis of finegrained dry powder mixes [17], silica particles [48], concrete with using recycling concrete aggregates [17] etc. For obtaining of new tables long labour-consuming experiences with using basic methods are needed $[13,14,15]$.

Task of project is expansion of methods for rapid definition of concrete's frost resistance, decreasing labour input and increasing operability. Also cost of testing is one of the most important problems in our day [46], but it's not purpose of existing manuscript.

\section{OFFERED METHOD FOR DETERMINATION OF CONCRETE'S FROST RESISTANCE}

Suppositive solution belongs to test methods of porous water-saturated bodies and is intended for definition of brand of concrete on frost resistance. That is number of standard cycles of freezing defrosting (for example, from +20 to $18 \pm 2^{\circ} \mathrm{C}$ for 4 hours), necessary for decreasing in strength of samples sated with water, at a size stipulated by the standard specification, in particular, for 5 or $15 \%$, i.e. relative decreasing in strength of $\Delta R / R=0,05 \ldots 0,15$.

Sample's long-time strength in the conditions of stretching correspond irreversible development of cracks in a concrete sample. Definition of relative tension set and long-time strength of a sample of a sample allows estimating the energy disseminated on processes destructions per unit of volume of material in the course of freezingdefrosting as per formula:

$\mathrm{W}_{\mathrm{tc}}=\theta_{\text {rel }} R_{\mathrm{It}}$

where:

$\mathrm{W}_{\mathrm{tc}}$ - the energy per unit of sample's volume disseminated in the course of freezing-defrosting;

$\Theta_{\text {rel }}$ - relative tension set of a sample;

$\mathrm{R}_{\mathrm{It}}$ - sample's long-time strength in the conditions of stretching;

$R_{\text {It }}$ is calculated by corresponding to it greatest nondestructive loading in the conditions of stretching $L_{0}$, which is determined by experiment. Longevity of concrete takes infinite value without outreaching $\mathrm{L}_{0}$. 
In our time concept of greatest nondestructive loading $L_{0}$ is usefully employed for express-monitoring different kinds of long resistance, such as durability (mechanical and exegetical), remaining life of product, longevity [29], frost resistance $[02,03,35]$, cracking resistance, erosion behaviour [30], corrosion [07] and time-dependent deformation [08].

In time of freezing development of concrete's damages is explained of subcritical cracks growth. In the brittle solids cracks begin to take off by shearing action [29], also speed of them development is no more than $10-4 \mathrm{~m} / \mathrm{s}[33,34]$. Therefore in conditions of freezing water filled crack in concrete capture of the nearby closed pores. It stabilize pressure in the water filled crack about the value causing in a material stretching tension, equal to long-time strength of a sample in the conditions of stretching.

If temperature body change since $78 \mathrm{~K}$ to 1493 $K$ and loading is like describing earlier, value $L_{0}$ shifts inside of deviation determination of it, i.e. $1 \div 3 \%$ [30]. This fact permit to use value $L_{0}$ received at a low temperature, when energy per unit of sample's volume disseminated in the course of freezing-defrosting is established.

Sample's loading in the conditions of monoaxial compression to extreme loading, registration these values of axial loading and axial strain, corresponding to loads, allows to calculate energy per unit of sample's volume disseminated in the course of its compression to extreme loading by numerical integration of dependence of axial loading from axial strain.. Value of the energy disseminated in unit of volume of a sample in the course of its compression to extreme loading, in proportion to a square of short-term strength [01]:

$$
\mathrm{W}_{\text {com }}=\alpha \mathrm{R}
$$

where:

$\mathrm{W}_{\text {com }}$ - the energy per unit of sample's volume disseminated in the course of its compression to extreme loading;

$\mathrm{R}$ - short-term strength;

$\alpha$ - proportionality coefficient.

The logarithmation of expression (2) and the subsequent differentiation introduce the dependence between relative decreasing in the energy disseminated per unit of volume of a sample in the course of its compression to extreme loading and relative decreasing in short-term strength:
$\Delta \mathrm{W} / \mathrm{W}_{\text {com }}=2 \Delta \mathrm{R} / \mathrm{R}$

where:

$\Delta \mathrm{W}$ - absolutely changing of energy

disseminated in unit of volume of a sample in the course of its compression;

$\Delta \mathrm{R}$ - absolutely changing of short-term strength;

The formula (3) allows to pass from relative decreasing in short-term strength allowed by the standard for concrete to admissible for a studied sample to relative decreasing in the energy $[\Delta \mathrm{W}]$ disseminated per unit of volume of a sample:

$\Delta \mathrm{W}=2 \mathrm{~W}_{\text {com }}[\Delta \mathrm{R} / \mathrm{R}]$

where:

$[\Delta \mathrm{W}]$ - standard absolutely changing of energy per unit of sample's volume disseminated in the course of its compression to extreme loading.

Thus, frost resistance as number of freezing defrosting will defined by the relation between admissible absolute changing of the energy per unit of volume of a sample disseminated in the course of compression and energy per unit of sample 's volume disseminated in the course of freezing defrosting, i.e. as per formula:

$\mathrm{F}_{\text {sam }}=[\Delta \mathrm{W}] / \mathrm{W}_{t c}$

where:

$\mathrm{F}_{\text {sam }}$ - concrete sample's frost resistance;

\section{REALIZATION OF OFFERED METHOD}

This way is realized as follows. First of all is making samples in the form of cylinders or cubes with an edge of $10 \mathrm{sm}$. from concrete mix of demanded structure. After curing samples are sated with water, measured. Further greatest non-destructive loading of LO is defined for each sample by a nondestructive testing, for example a method of acoustic emission [30, 31]. Without outreaching $L_{0}$ a sample's crack doesn't develop yet in the conditions of stretching. Expedient stretching tension in cylinders or cubes is created compression of them on lines of contact of cylinders with the plane (splitting). If LO is determined, it is possible to calculate a limit of long durability for the tested sample:

$\mathrm{R}_{\mathrm{tt}}=2 \mathrm{~L}_{0} / \pi \mathrm{S}$ 
where:

S-area of section of a sample, perpendicular compression planes;

$\mathrm{L}_{0}$-the greatest nondestructive loading of a sample in the conditions of stretching.

After sample's freezing-defrosting up to the standard temperatures and definition of relative tension set of a sample it's possible to calculate the energy per unit of sample's volume disseminated in the course of its freezing defrosting as per formula (1).

Further, a sample is squeezed in the conditions of monoaxial compression to extreme loading, and the current values of axial loading and relative tension set of a sample corresponding to them are registered. Numerical integration of dependence of axial loading from absolute relative tension set of a sample and distribution of its result on the volume of a sample allows calculating the energy per unit of volume of a material disseminated before achievement of extreme loading. Frost resistance for a concrete sample Fsam is calculated by the received results as per formula:

$$
\mathrm{F}_{\text {sam }}=2[\Delta \mathrm{R} / \mathrm{R}] \cdot \mathrm{W}_{\text {com }} / \mathrm{W}_{\mathrm{tc}}
$$

where:

Concrete's frost resistance is found as an average of values of frost resistance for samples. Confidential interval of concrete's frost resistance is counted on dispersion of values of frost resistance for a series of samples.

In particular, this way was realized on 10 samples cubes, an edge of $10 \mathrm{~cm}$ at the age of 88 days made of a concrete mix of such structure: Brand 400-1 portlandtsement weight part, sand -2 weight parts, granite rubble $5 \ldots 20 \mathrm{~mm}-4,5$ weight parts, waters $-0,6$ weight parts. It is experimentally established in two different ways for this concrete at the age of 88 days that after 105 freezing-defrosting corresponding to brand of this concrete on frost resistance, average relative decreasing in strength makes 0,142 on a way [30] and 0,16 on the basic way [19], that is both values lie within an error of the used ways. On the average relative decreasing in strength makes $15 \%$.

Samples have been sated with water according to item state standard specification, measured and registered volume. For each sated with water cube splitting according to item value of the greatest nondestructive loading (without which excess of a crack in a sample don't develop yet is irreversible) were defined. After each test the plane of compression of a sample was changed for the perpendicular plane to previous compression. Definition of the greatest nondestructive loading carried out by means of an acoustic issue way, using the AF-15 AE-complex of Kishenevskiy manufacture. Acoustic sensors with a frequency of $20-200 \mathrm{kHz}$ established on the verge of a sample, parallel to plane of compression. For creation of axial loading a hydraulic press was used. By received value of the greatest nondestructive loading, corresponding to it value of a sample's long-time strength in the conditions of stretching was counted. Then average value of a long-time strength was counted too. Results of calculating are given in the table.

The water-saturated samples were placed in the measuring camera of the differential volume dilatometer DOD-100-K, and in its second camera a standard aluminum sample was placed. Both cameras were filled with kerosene and pressurized. The dilatometer with samples was installed in the freezer and after $30 \mathrm{~min}$. endurance freezing with a speed $0,3^{\circ} \mathrm{C} /$ mines before achievement of temperature $(-18 \pm 2){ }^{\circ} \mathrm{C}$ was began. According to the dependency diagrams of differences, relative volume tension set of a concrete and aluminum sample was calculated. Energy per unit of sample's volume disseminated in the course of its freezing-defrosting as per formula (1) for each sample.

Further average value of sample's long-time strength in the conditions of stretching was defined as arithmetic average RIt values long-time strength in the conditions of stretching.

Axial compression of samples by splitting [52] with a speed of $400 \mathrm{~kg} / \mathrm{sec}$. carried out on the hydraulic press equipped with the graph plotter of dependence of axial loading from axial strain. Values on a dynamometer are determined by the location of the conducted and conducting arrows being part of the closed electronic chain with a control bulb. Removal of sample's loading was begun on a signal of the control bulb, which is switched off by electro contacts on a conducted and conducting arrow of a dynamometer. The conducted arrow of a dynamometer press registered value of the maximum loading. By the dependence received on the graph plotter the area under it was determined, i.e. received the 
energy disseminated per volume of a sample in the course of its compression to extreme loading. The energy per unit of sample's volume disseminated in the course of its compression to extreme loading, was received as per formula (8):

$\mathrm{W}_{\text {com }}=\mathrm{W} / \mathrm{N}$

where:

W-energy disseminated of sample in the course of its compression to extreme loading;

V-sample's volume.

Then for each sample brand of a concrete sample on frost resistance was counted (Table 1) as number of freezing defrosting necessary for decrease in its strength for $15 \%$ on as per formula (7).

Further, an average for values of the $\mathrm{F} 15 \mathrm{i}$, and an average square deviation of results of experience were calculated:

$$
\mathrm{S}=\frac{\sqrt{\left(F_{15 i}-\overline{F_{15}}\right)}}{3}
$$

where:

$\mathrm{S}-$ an average square deviation of results of experience;

$\mathrm{F}_{15 i^{-}}$the value concrete i-sample on frost resistance at decreasing sample's short-term strength in the conditions of compression for $15 \%$, received by the offered way; where $i$ is changed since 1 to 10 ;
$\left(F_{15}\right)$ - concrete's frost resistance, equal to arithmetic-mean value of frost resistance for series of concrete samples at decreasing theirs shortterm strength in the conditions of compression for $15 \%$.

The average square deviation of $F_{15 i}$ values was equal 16. Taking into account it, a divergence of average value of frost resistance of concrete is take on 99,7 and the earlier experimentally found number of cycles 105 ( $F_{15}$ brand) necessary for decreasing $\mathrm{R}$ for $15 \%$, it is possible to consider casual, and the offered way is correct.

\section{SUMMARY}

The offered way expands a list of technical means for the rapid definition of concrete's frost resistance. Duration of determination of frost resistance is caused by the time of sample's water saturation (4 days according to standard specification [19]). In our time, there is existing pending patent application for offered way. Detailed researches and pilot studies are necessary to get more data that are experimental and create new method of determination of frost resistance in future.

Table 1: Definition type concrete's frost resistance as per offered method

\begin{tabular}{|c|c|c|c|c|c|c|}
\hline № & $\mathrm{R}_{\mathrm{lt}} \mathrm{MPa}$ & Oten・104 & $\mathrm{W}_{\mathrm{tc}} \cdot 10^{4} \mathrm{MPa}$ & $\begin{array}{c}\mathrm{W}_{\text {com }} \cdot 10, \\
\mathrm{MPa}\end{array}$ & $\begin{array}{c}{[\Delta \mathrm{W}] \cdot 10^{2},} \\
\mathrm{MPa}\end{array}$ & $\mathrm{F}_{15 \mathrm{i}}$ \\
\hline 1 & 1,5 & 2,7 & 4,05 & 0,9990 & 2,997 & 74 \\
\hline 2 & 1,7 & 3,1 & 5,27 & 1,7215 & 5,165 & 98 \\
\hline 3 & 1,8 & 1,8 & 3,24 & 1,2312 & 3,694 & 114 \\
\hline 4 & 1,9 & 2,6 & 4,90 & 1,6796 & 5,039 & 102 \\
\hline 5 & 2,0 & 2,5 & 5,00 & 1,4333 & 4,300 & 86 \\
\hline 6 & 2,1 & 1,9 & 4,00 & 1,4364 & 4,309 & 108 \\
\hline 7 & 2,2 & 2,6 & 5,72 & 2,2308 & 6,692 & 117 \\
\hline 8 & 2,3 & 2,1 & 4,83 & 1,3846 & 4,154 & 86 \\
\hline 9 & 2,9 & 1,8 & 5,22 & 1,6008 & 4,802 & 92 \\
\hline 10 & 3,1 & 1,5 & 4,65 & 1,8600 & 0,558 & 120 \\
\hline Average & 2,15 & 2,1 & 4,69 & 1,5577 & - & 99,7 \\
\hline
\end{tabular}




\section{REFERENCES}

1) Ahverdev I.N. (1981) Osnovy fiziki betona, Moscow: Strojizdat.

2) Akimov S.V., Nikolskaya T.S. at al. (2010) Sposob opredelenija morozostojkosti kamnja, RU Patent 2380681.

3) Akimov S.V., Nikolskaya T.S. at al. (2009) Obrazec dlja szhatija kamnja pri ocenke ego morozostojkosti, RU Patent 2370767.

4) Alihodzic, R., Murgul, V., Vatin, N., Aronova, E., Nikolić, V., Tanić, M., Stanković, D. (2014): Renewable Energy Sources used to Supply Pre-school Facilities with Energy in Different Weather Conditions. Applied Mechanics and Materials. Vol. 624. pp. 604-612

5) Aronova, E., Murgul, V. (2013): The evaluation of the appropriateness for using solar energy technologies in the historical building of SaintPetersburg and the climatic conditions of the North-West region, Architecture and Modern Information Technologies, 2 (23), pp. 97-117

6) Aronova, E., Radovic, G., Murgul, V., Vatin, N. (2014): Solar Power Opportunities in Northern Cities (Case Study of Saint-Petersburg). Applied Mechanics and Materials. Vols. 587-589, pp. 348-354

7) Barabanthikov U.G. at al. (2012) Sposob ocenki stojkosti izdelij pri nagruzhenii, RU Patent 2442134.

8) Belyaeva S.V. at al. (2012) Sposob ocenki korrozionnoj stojkosti betonnyh izdelij, RU Patent 2449266.

9) Benin, A.V., Semenov, A.S., Semenov, S.G., Melnikov, B.E. (2012): Konechno-jelementnoe modelirovanie processov razrushenija i ocenka resursa jelementov avtodorozhnogo mosta s uchetom korrozionnyh povrezhdenij, Magazine of Civil Engineering, Vol.33, No.7, pp. 32-42.

10) Bunke, N. (1991): Prüfung von Beton - Empfehlungen und Hinweise als Ergänzung zu DIN 1048, Schriftenreihe des Deutschen Ausschusses für Stahlbeton, No. 422, pp.12-15.

11) Cherepanov, V.I., Nekrasova, E.V., Chernyh, N.A., Panchenko, Ju.F. (2013): Vodostojkost' silikatnogo kirpicha, Construction Materials, No.9, pp. 10-12. Davie C.T., Pearce C.J., Bićanić N. (2005): Effects of Fluid Transport on the Structural Integrity of Concrete Nuclear Pressure Vessels, Proceeding of the 13 ACME conference: University of Sheffield, pp. 35-46.
12) Dikun A.D. at al. (2005): 'Opyt jekspressnogo opredelenija morozostojkosti betona transportnyh sooruzhenij', Construction Materials, No. 8, pp. 55-56.

13) Dikun A.D. at al. (2004): 'Razvitie otechestvennogo dilatometricheskogo metoda prognozirovanija svojstv betona', Construction Materials, No. 4, pp. 52-56.

14) Dikun A.D. at al. (2003): 'Prognozirovanie morozostojkosti betona', Construction Materials, No. 11, pp. 28-30

15) Gehlen C. (2011) Compilation of Test Methods to Determine Durability of concrete, Germany: critical review RILEM Technical Committee TDC.

16) Gokce A., Nagataki C., Saeki T., Hisada M. (2010) Identification of frost-susceptible recycled concrete aggregates for durability of concrete, Construction and building materials, Vol. 25, No.5, pp. 2426-2431.

17) Gorchakov G.I., Kapkin M.M., Skramtaev B.G. (1965) Povyshenie morozostojkosti betona $v$ konstrukcijah promyshlennyhigidrotehnicheskih sooruzhenij, Moscow: Strojizdat

18) Interstate Council for Standardization, Metrology and Certification (1995) Concretes. Methods for the determination of frost-resistance., GOST, Russia.

19) Kalashnikov V.I., Tarakanov O.V., Kusnetsov Y.S., Volodin V.M., Belyakova E.A. (2012) Next generation concrete on the basis of fine-grained dry powder mixes, Magazine of Civil Engineering, Vol. 34, No. 8, pp. 47-53.

20) Kiski S.S., Ageev I.V., Ponomarev A.N., Kozeev A.A., Judovich M.E. (2012): Issledovanie vozmozhnosti modifikacii karbosilatnyh plastifikatorov $v$ sostave modificirovannyh melkozernistyh betonnyh smesej, Magazine of Civil Engineering, Vol. 34, No.8, pp. 42-46.

21) Kljuev S.V. (2012): High-strength fiber concrete for industrial and civil construction, Magazine of Civil Engineering, Vol. 34, No.8, pp. 61-66.

22) Kosior-kazberuk M. (2013): Variation in fracture energy of concrete subjected to cycling freezing and thawing, Arhives of civil and mechanical engineering, Vol.13, No.2, pp.254-259.

23) Kurilko A.S. , Novopashin M. D. (2005): Features of Low Temperature Effect upon Strength of Enclosing Rock and Kimberlite in the "Udachnaya" Pipe, Journal of Mining 
Science, Vol. 41, No. 2, pp 119-122.

24) Lazarevska, M., Milanovic, M., Knezevic, M., Cvetkovska, M., Trombeva-Gavriloska, A., Samardzioska, T. (2014): An artificial neural network prediction model for fire resistance of composite columns, Journal of Applied Engineering Science, Vol. 12, № 1, pp 63-68

25) Murgul, V.: Solar energy in the reconstruction of urban environment of historic building SaintPetersburg, Architecture and Modern Information Technologies, 2 (23) (2013), pp. 1-24.

26) Murgul, V.: Solar energy systems in the reconstruction of heritage historical buildings of the northern towns (for example SanktPetersburg). Journal of Applied Engineering Science, Vol. 12 (2) (2014), pp 121-128

27) Murgul, V. (2014): Features of energy efficient upgrade of historic buildings (illustrated with the example of Saint-Petersburg), Journal of Applied Engineering Science, Vol. 12, № 1, pp 1-10

28) Nemova, D., Murgul, V., Golik, A., Chizhov, E., Pukhkal, V., Vatin N. (2014): Reconstruction of administrative buildings of the 70s: the possibility of energy modernization, Journal of Applied Engineering Science, Vol. 12, № 1, pp 37-44

29) Nesvetaev G.V., Kardumjan G.S. (2013): Prochnost' cementnogo kamnja s superplastifikatorami i organomineral'nymi modifikatorami s uchetom ego sobstvennyh deformacij pri tverdenii, Beton i zhelezobeton, No.5, pp. 6-8.

30) Nikolskaya T.S. (2002): 'Particularities of Acoustic Emission in Ceramic Product under Partial Uploading', Problems of Strength, Vol.356, No. 1, pp. 140-147.

31) Nikolskaya, T.S., Nikolskiy, S.G. (2008): 'Akusticheskaja jemissija pri jerozii melkozernistogo betona', Nauchno-tehnicheskie vedomosti SPBGPU, Vol. 4, No. 4, pp. 242-248

32) Nikolskaya T.S., Nikolskiy S.G., Terentiev V.P. (2009) 'Jekspress-metody ocenki dlitel'noj stojkosti betona', Proceeding of the III international conference at St.Petersburg "Populjarnoe betonovedenie", pp. 67-83

33) Nikolskiy S.G. (2009): 'Fracture Surface Analysis of Ceramic Bare under Short- and Long-term Bending', Problems of Strength, Vol.401, No. 5, pp. 133-140.

34) Nikolskiy S.G. (2008): 'Jekspress-kontrol' jerozii betona', Magazine of Civil Engineering, Vol.2, No. 2, pp. 39-44
35) Nikolskiy S.G. (1990): 'Acoustic emission control of strength', Problems of Strength, Vol.252, No. 6, pp. 102-106.

36) Nikolskiy S.G., Vorontcova E.A. (2012) Sposob opredelenija vodocementnogo otnoshenija betona po trebuemoj morozostojkosti pri proektirovanii, RU Patent 2490631

37) Pavlicic, N., Perazic, M., Djuric-Jocic, D., Knezevic, M., (2014): Engineering education in the field of civil engineering, Journal of Applied Engineering Science, Vol. 12, № 1, pp 11-18

38) Ponomarev, A.N. (2009): Vysokokachestvennye betony. Analiz vozmozhnosteľ i praktika ispol'zovanija metodov nanotehnologii, Magazine of Civil Engineering, Vol. 8, No. 6, pp. 25-33.

39) Radovic, G., Murgul, V., Vatin, N.(2014): Fast urban development of Cetinje - old royal capital of Montenegro. Applied Mechanics and Materials. Vols. 584-586, pp. 564-569

40) RILEM Technical Committee (2004) CIF Test, Test Method of frost resistance of concrete,

41) RILEM TC 176 Recommendation, Germany.

42) RILEM Technical Committee (1996) TDC, CDF Test, Test Method for the Freeze-Thaw-Resistance of concrete with sodium chloride solution, RILEM TC 117-FDC Recommendation, Germany.

43) Rønning T.F. (2001) Freeze-Thaw Resistance of Concrete. Effect of Curing Conditions, Norway: Norwegian Institute of Technology.

44) Samardzioska, T., Trombeva-Gavriloska, A., Cvetanovski, P., Popovski, D., Partikov, M., (2012): Strengthening and overbuilding of car service "Automakedonija» in Skopje, Makedonija, Journal of Applied Engineering Science, № 1 (10), pp. 53-58

45) Shashank, B. (2004) Strain variations in concrete subjected to cyclic freezing and thawing, Tokyo: Thesis Submitted to University of Tokyo Department of Civil Engineering.

46) Shanshan, J., Jinxi, Z., Baoshan, H. (2013): Fractal analysis of effect of air void on freezethaw resistance of concrete, Construction and Building Materials, Vol. 47, pp. 126-130.

47) Sprince, A.A, Fischer, G.A., Pakrastinsh, L.A., Korjakins, A.A. (2014): Crack propagation in concrete with silica particles, Advanced Materials Research, 842, pp. 470-476.

48) Sprince, A.A., Pakrastinsh, L.A, Korjakins, A.B. (2011): Experimental study on creep of new concrete mixtures, Civil Engineering 
'11 - 3rd International Scientific Conference, Proceedings, 3, pp. 20-26.

49) Swedish Standard (2005) Concrete testing - Hardened Concrete-Frost Resistance, SS 137244, Sweden.

50) Toturbiev A.B., Cherkashin V.I., Macapulin V.U., Toturbiev B.D. (2013): Zharostojkij beton na mestnom prirodnom nanodispersnom kremnezemistom syr'e, Beton i Zhelezobeton, No.6, pp. 2-5

51) Vatin N., Nazmeeva T., Guslinscky R. (2014) Problems of cold-bent notched c-shaped profile members. Advanced Materials Research. Vols. 941-944. pp 1871-1875

52) Vatin N., Havula J., Martikainen L., Sinelnikov A., Orlova A., Salamakhin S. (2014). Thin-walled cross-sections and their joints: tests and FEM-modelling. Advanced Materials Research Vols. 945-949. pp 1211-1215

53) Vatin V., Nemova D., Kazimirova A., Gureev K. (2014). Increase of energy efficiency of the building of kindergarten. Advanced Materials Research. Vols. 953-954 (2014) pp 1537-1544

54) Vuksanovic, D., Murgul V., Vatin, N., Aronova E. (2014): Shadowing impact on amount of power generated by photovoltaic modules. Applied Mechanics and Materials. Vols. 587589, pp. 342-347

55) Ulybin, A.V. (2012): On the Choice of Concrete Strength Inspection Methods of Readybuilt Structures, Magazine of Civil Engineering, Vol. 34, No. 8, pp. 42-46

Paper sent to revision: 08.05.2014.

Paper ready for publication: 14.03.2015. 